\title{
First report of Aculops lycopersici (Tryon, 1917) (Acari: Eriophyidae) on Pepino in Turkey
}

\author{
R. Akyazi \\ University of Ordu, Faculty of Agriculture, Department of Plant Protection, Ordu, Turkey
}

\begin{abstract}
The tomato russet mite, Aculops lycopersici (Tryon, 1917) (Acari: Eriophyidae) is reported for the first time on Pepino (Solanum muricatum Aiton) in Ordu and Samsun provinces in Turkey.
\end{abstract}

\section{Short paper}

Aculops lycopersici (Tryon, 1917) (Acari: Eriophyidae) is known as tomato russet mite or tomato rust mite. It was described as Phyllocoptes lycopersici Tryon in 1917 from samples collected in Queensland, Australia. The same mite was later described as a new species by Massee (1937) with the same name, and later by Keifer (1940) as Phyllocoptes destructor (synonymized by Keifer, 1952). Geographical distribution of $A$. lycopersici, first described from Queensland, Australia, has been expanded to include the Afro-tropical region, Australian region, East Palaearctic (east of the border line here defined), Near East (Asian Turkey, Caucasian Russian Republics, Georgia, Armenia, Azerbaijan, Lebanon, Syria, Israel, Jordan, Sinai Peninsula (Egypt), Arabian Peninsula, Iran, Iraq), Nearctic region,

Correspondence: Rana Akyazi, University of Ordu, Faculty of Agriculture, Department of Plant Protection, Ordu, Turkey.

Tel. +9.452.234.50.10 - Fax: +9.452 .234 .66 .32 .

E-mail: ranainak@hotmail.com

Key words: Aculops lycopersici, Pepino, Solanum muricatum, Turkey.

Acknowledgments: we thank Mariusz Lewandowski (Department of Applied Entomology, Faculty of Horticulture and Landscape Architecture, Warsaw University of Life Sciences, Warsaw, Poland) for confirmation of the eriophyid species.

Received for publication: 16 August 2012.

Revision received: 30 October 2012.

Accepted for publication: 14 November 2012.

(C) Copyright R. Akyazi, 2012

Licensee PAGEPress, Italy

Journal of Entomological and Acarological Research 2012; 44:e20

doi:10.4081/jear.2012.e20

This article is distributed under the terms of the Creative Commons Attribution Noncommercial License (by-nc 3.0) which permits any noncommercial use, distribution, and reproduction in any medium, provided the original author(s) and source are credited.
Neotropical North African region (not including the Sinai Peninsula), oriental regions (de Lillo, 2004; Anonymous, 2012a). Aculops lycopersici occurs on some Solanaceae (Jeppson et al., 1975; Özman-Sullivan \& Öcal, 2005), few Convolvulaceae and Rosaceae. It is mostly known as a pest of tomatoes, but also damages potato (Solanum tuberosum L.), eggplant (brinjal) (Solanum melongena L.), tobacco (Nicotiana tabacum L.), bell pepper (Capsicum annuum L.), Jerusalem cherry (Solanum pseudocapsicum L.), petunia (Petunia hybrida L.), tomatillo (Physalis philadelphica Lam.), cherry pepper (Capsicum annuum var. annuum L.), hairy nightshade (Solanum sarrachoides (Sendtner)), black nightshade (nightshade) (Solanum nigrum L.), small flowered nightshade (Solanum nodiflorum Jacq.), popolo (Solanum nelsonii Dunal.), horse nettle (Solanum carolinense L.), jimson weed (Datura stramonium L.), tolguacha (Datura meteloides Dunal.), Chinese thorn apple (Datura quercifolia Kunth), amethyst (Browallia speciosa Hook.), poha (cape gooseberry) (Physalis peruviana L.) (Perring, 1996; Duso et al., 2010), hot pepper (Capsicum frutescens L.), sweet potato (Ipomoea batatas (L.)), long-spined thornapple (Datura ferox L.), thornapple (Datura innoxia P.Mill.), wild tomato (Lycopersicon peruvianum L.), red currant tomato (Lycopersicon pimpinellifolium (L.)), native gooseberry (Physalis minima Linn.), Jamaican Forget Me Not (Browallia americana L.) (Solanales: Solanaceae) (Craemer, 2002), field bindweed (Convolvulus arvensis L.), Morning Glory (Pharbitis nil L.) (Perring, 1996; Duso et al., 2010; Anonymous, 2012b) and tall Morning Glory (Ipomoea purpurea L.) (Solanales: Convolvulaceae) (Hoy, 2011), wild blackcurrant (Ribes americanum Mill.), wild gooseberry (Ribes hirtellum Michx.) and blackberry (Rubus caesius L.) (Rosales: Rosaceae) (Perring, 1996; Duso et al., 2010). Larrain (2002) recently found this mite on pepino (Solanum muricatum Aiton) in Chile.

In August 2010 and September 2011, Aculops lycopersici and its typical symptoms such as bronzing of leaves, withering and change of stem color from green to brown were found on $S$. muricatum plants in Kayabaşı village in Ordu and Terme province in Samsun, both in the Black Sea Region of Turkey. The leaves expected to be contaminated were collected in individual polyethylene bags in August 2010 and September 2011 and brought to the laboratory. The mites on the leaves were collected by brush under a microscope. Eriophyids were preserved in vials containing $70 \%$ ethanol. The mites were moved separately to watch glasses containing lactophenol as a clearing medium. Each mite was mounted in a drop of Hoyer's medium and the microscope slides were dried at $60^{\circ} \mathrm{C}$. The slide mounts were studied under different magnifications (Walter \& Krantz, 2009). The mites were identified according to Keifer et al. (1982). The species was confirmed by Mariusz Lewandowski. These were the first records of $A$. lycopersi$c i$ infection on pepino in Turkey. Since there is no literature on $A$ lycopersici of pepino fruit grown in Turkey, this plant was recorded as a new host for Turkey.

In Turkey, the species was initially recorded on open-air tomato crops in Adana and Içel provinces (Şekeroğlu \& Özgür, 1984), and later 
on tomato plants in field and glasshouses at Adana, Içel, Antalya, Manisa, İzmir, Samsun, Tokat provinces of Turkey (Öncüer et al., 1992; Can \& Çobanoğlu, 2004; Madanlar \& Öncüer, 1994; Yaşarakıncı \& Hıncal, 1997; Yoldaş et al., 1999; Hıncal et al., 2002; İnal, 2005; Yanar et al., 2008; Güncan et al., 2010). Tomato russet mite was also found on $S$. nigrum in the tomato fields in Tokat province (Yanar et al., 2008). So it seems likely that the presence of this species on $S$. muricatum in Ordu and Samsun provinces, where plants of the Solanaceae family can be grown, should not be surprising. However, there are currently no records from any plants in Ordu and from $S$. muricatum in Turkey.

\section{References}

ANONYMOUS, 2012a - Aculops lycopersici. Available from: http://www. faunaeur.org/distribution_table.php

ANONYMOUS, 2012b - Tomato russet mite (Aculops lycopersici) Host plants/species affected. Available from: http://www.plantwise.org/ ?dsid $=56111$ \&loadmodule $=$ plantwisedatasheet $\&$ page $=4270 \&$ site $=234$

CAN M., ÇOBANOĞLU S., 2004 - Antalya İli Kumluca yöresinde sebze üretimi yapılan plastik ve cam seralarda bulunan akar (Acarina) türlerinin tanımı, konukçuları ve yoğunluklarının belirlenmesi üzerine araştırmalar [Studies on the determination of mite (acarina) species their hosts and population densities on greenhouse vegetable in Kumluca Antalya]. A. Ü. Fen Bilimleri Enstitüsü, Yüksek Lisans Tezi, Ankara.

CRAEMER C., 2002 - Aculops lycopersici, host notes. Available from: http://ecoport.org/ep?Arthropod=18684\&entityType $=\mathrm{AR}^{* * * *}$ \&entit yDisplayCategory $=\mathrm{AR}^{* * * *} 3000$

DE LILLO E., 2004 - Fauna Europaea: Eriophyoidea. In: MAGOWSKİ W. Fauna Europaea: Acariformes. Fauna Europaea version 1.1. Available from: http://www.faunaeur.org/full_results.php?id=93787

DUSO C., CASTAGNOLI M., SIMONI S., ANGELI G., 2010 - The impact of eriophyoids on crops: recent issues on Aculus schlechtendali, Calepitrimerus vitis and Aculops lycopersici. - Exp. Appl. Acarol. 51: 151-168.

İNAL B., 2005. - Bafra ve Çarşamba ovalarında çeşitli kültür bitkisi alanlarında bulunan Acarina türleri üzerinde faunistik çalışmalar (Faunistic studies on the acarina species found on various crops in Bafra and Çarşamba plains). Ondokuz Mayı Üniversitesi Fen Bilimleri Enstitüsü, Yüksek Lisans Tezi, Samsun.

GÜNCAN A., MADANLAR N., YOLDAŞ Z., ERSİN F., TÜZEL Y., 2010 İzmir ilinde örtüaltı organik sebze üretiminde topraküstü zararlılarının durumu [Status of above-ground pests in organic vegetable production under greenhouse conditions in İzmir province]. Türk. Entomol. Derg. 34: 503-513.

HINCAL P., YAŞARAKINCI N., ÇINARLI İ., 2002 - İzmir ilinde Domates pas akarı (Aculops lycopersici Massee) (Acarina: Eriophyidae)'nın popülasyon seyri, doğal düşmanları ve kimyasal mücadelesi üzerinde araştırmalar [The researches on the population developments of Aculops lycopersici (Massee) (Acarina:Eriophyidae) and its natural enemies, the chemical control of the pest in İzmir]. Bit. Kor. Bült. 42: 9-22.
HOY M.A., 2011 - Agricultural acarology: Introduction to integrated mite management. -CRC Press, Taylor and Francis Group, Boca Raton, London, New York.

JEPPSON L.T., KEIFER H.H., BAKER E.W., 1975 - Mites Injurious to economic plants.- University of California Press, Berkley, CA.

KEIFER H.H., 1940 - Eriophyid studies. - X. Bull. Calif. Dept. Agric. 29: 160-179.

KEIFER H.H., 1952 - The Eriophyid mites of California (Acarina, Eriophyidae). - Bull. Calif. Insect Surv. 2: 1-123.

KEIFER H.H., BAKER E.W., KONO T., DELFINADO M., STYER W.E., 1982 An illustrated guide to plant abnormalities caused by Eriophyid mites in North America. U.S. Department of agriculture, Agricultural Research Service, Agriculture Hand Book, Washington, DC.

LARRAIN S.P., 2002 - Insect and mite pest incidence on sweet pepinos Solanum muricatum (Ait.) cultivated in the IV Region, Chile. - Agr. Tec. 62: 15-26.

MADANLAR N., ÖNCÜER C., 1994 - İzmir ilinde sera domatesi zararlsı olarak Aculops lycopersici (Massee) (Acarina, Eriophyidae) [Aculops lycopersici (Massee) (Acarina, Eriophyidae) a pest of greenhouse tomatoes in İzmir province]. - Türk. Entomol. Derg. 18: 237-240.

MASSEE A.M., 1937 - An eriophyid mite injurious to tomato. Bull. Ent. Res. 28: 403.

ÖNCÜER C., KARSAVURAN Y., YOLDAȘ Z., DURMUŞOĞLU E., 1992 Sanayi domateslerinde görülen zararlılar, yayılış ve bulaşma oranları üzerinde araştırmalar [Investigation on process tomato pests and their distribution and infestation rates]. In: Türkiye II. Entomoloji Kongresi Bildirileri, Adana: 705.

ÖZMAN-SULLIVAN S.K., ÖCAL H., 2005 - Sebzelerde Bulunan Eriophiyoid Akarlar [Eriophyoid mites on vegetables]. GAP IV. Tarım Kongresi Bildirileri, Cilt 1, Şanlıurfa: 334-341.

PERRING T.M., 1996 - Vegetables. In: LINDQUIST E.E., SABELIS M.W., BRUIN J., (eds.). Eriophyid mites their biology, natural enemies and control. World Crop Pests. Elsevier, Amsterdam: 593-610.

ŞEKEROĞLU E., ÖZGÜR A.F., 1984 - A new tomato pest in Çukurova, Aculops lycopersici (Massee) (Acarina: Eriophyidae). - Turk J. Plant Protect. 8: 211-213.

TRYON H., 1917 - Report of the entomologist and vegetable pathologist Queensland Dept. Agric. and Stock Rept., Queensland: 49-63.

WALTER D.E., KRANTZ G.W., 2009 - A manual of acarology. In: KRANTZ G.W., WALTER D.E., (eds.). Collection, rearing and preparing specimens. Texas Tech University Press, Lubbock, TX: 83-97.

YANAR D., ECEVIT 0., KADIOĞLU İ., 2008 - Tokat yöresinde domates ekim alanlarında zarar oluşturan domates pas akarı Aculops lycopersici (Massee) (Acari: Eriophyidae) [Tomato rust mite Aculops lycopersici (Massee) (Acari: Eriophyidae) causing damage in tomato production areas of Tokat]. - G.O.P Üniv. Zir. Fak. Derg. 25: 1-5.

YAŞARAKINCI N., HINCAL P., 1997 - İzmir'de örtüaltında yetiştirilen domates, hıyar, biber ve marulda bulunan zararlı ve yararlı türler ile bunların popülasyon yoğunlukları üzerinde araştırmalar [The Research on determining the pests and beneficial species and their population densities on the tomato, cucumber, pepper and lettuce glasshouses in İzmir]. Bit. Kor. Bült. 37: 79-89.

YOLDAŞ, Z., MADANLAR N., GÜL A., ONOĞUR E., 1999 - Investigations on integrated control practices in vegetable glasshouses in Izmir. Acta Hort. 491: 453-460. 